\title{
A study of charge exchange in a residual-effected HCCI gasoline engine
}

\author{
An in-cylinder charge exchange process in a gasoline homogeneous charge compression ignition (HCCI) engine op- \\ erated in a negative valve overlap (NVO) mode was studied. Research was performed using a single-cylinder research \\ engine with fully variable valve actuation. Combination of in-cylinder pressure traces processing and fluid flow model \\ enables cycle-by-cycle analysis of charge composition and temperature. It allows forecasting of in cylinder pressure- \\ volume and temperature-volume histories and can be used for physical-based engine control. In this paper influence of \\ valves timings and valves lifts on the gas exchange process was analyzed. Special attention was paid to the effects of \\ backflows of the in cylinder charge to an intake port.
}

Key words: HCCI, gasoline, negative valve overlap, variable valve actuation

\section{Analiza procesu wymiany ladunku w benzynowym silniku HCCI $\mathrm{z}$ wewnętrzną recyrkulacją spalin}

\begin{abstract}
W artykule przedstawiono wyniki analizy procesu wymiany ladunku w benzynowym silniku HCCI (ang. homogeneous charge compression ignition) działającym z ujemnym współotwarciem zaworów. Badania eksperymentalne zostały przeprowadzone na jednocylindrowym silniku badawczym wyposażonym w uklad zmiany faz rozrządu i wzniosu zaworów. Połaczenie analizy ciśnienia indykowanego w cylindrze i modelu przepływu czynnika roboczego pozwala na określanie składu oraz temperatury czynnika w cylindrze z rozdzielczościa cyklową. Dzięki temu możliwe jest przewidywanie przebiegów krzywych temperatury i ciśnienia sprężania, co może być wykorzystane do sterowania silnika w oparciu o model fizyczny. W niniejszej pracy dokonano analizy wpływu zmiennych faz rozrządu i zmiennego wzniosu zaworów na proces wymiany tadunku. Szczególnq uwagę zwrócono na efekty przepływów zwrotnych z cylindra do kanału dolotowego.

Słowa kluczowe: HCCI, silnik benzynowy, ujemne współotwarcie zaworów, zmienny układ rozrządu
\end{abstract}

\section{Introduction}

Auto-ignition of homogeneous charge is an alternative to spark ignition engines, both with homogeneous and stratified charge combustion. Spontaneous commencement of combustion in a whole in-cylinder volume results in a thermal efficiency comparable to stratified mixture combustion. A decrease in the in-cylinder temperature allows a substantial reduction of the emission of nitrogen oxides. An engine able to realize HCCI (homogeneous charge compression ignition) in some part of the load-speed map can be equipped with a 3-way catalytic converter, even if the engine is fed with a lean mixture.

Recently, a rapid development of this combustion system has been observed. The most production-feasible solution for a HCCI engine is the use of internal exhaust re-circulation (residual effect) obtained by a negative valve overlap (NVO). The combination of a fully variable valvetrain system with a direct gasoline injection allows controlling of the combustion course and exhaust emissions.

The idea of the HCCI engine with internal exhaust re-circulation is based on the organization of the charge exchange process. As a result, auto-ignition temperature of the mixture occurs at the same crank angle position, independently of engine load and speed conditions.

The aim of this study is a presentation of the mechanism, which is the key to stable operation of HCCI engines. Such an engine does not need active, closed loop control of the heat release rate. This paper is a continuation of author's previous works in this field $[4,5]$.

\section{Wprowadzenie}

Samozapłon mieszanek jednorodnych stanowi alternatywę dla silników o zapłonie iskrowym, spalających zarówno ładunek homogeniczny, jak i uwarstwiony. Zapłon mieszanki w wielu miejscach komory spalania jednocześnie sprawia, że sprawność silnika jest porównywalna z systemami spalania ładunku uwarstwionego. Dzięki obniżeniu temperatury spalania emisja tlenków azotu ulega radykalnemu obniżeniu. Taki silnik, który realizuje proces spalania HCCI (homogeneous charge compression ignition) może pracować przy ubogich mieszankach, współpracując z trójfunkcyjnym reaktorem katalitycznym spalin.

Obecnie trwają intensywne prace nad rozwojem tego systemu spalania. Jedynym rozwiązaniem, które nadaje się do praktycznego wykorzystania jest wewnętrzna recyrkulacja spalin uzyskana dzięki ujemnemu współotwarciu zaworów. Połączenie takiego sposobu wymiany ładunku (całkowicie zmienny układ rozrządu) z bezpośrednim wtryskiem paliwa pozwala na kontrolę przebiegu spalania i emisji toksycznych składników spalin.

Istota działania silnika HCCI z wewnętrzną recyrkulacją spalin oparta jest na unikalnym przebiegu procesu wymiany ładunku. W wyniku jego realizacji temperatura samozapłonu mieszanki osiągana jest przy odpowiednim położeniu wału korbowego, niezależnie od obciążenia silnika i prędkości obrotowej.

Celem pracy jest przedstawienie mechanizmu odpowiedzialnego za stabilną pracę silnika HCCI bez konieczności 
The course of the charge exchange in the HCCI engine, operated in NVO mode, is significantly different than the course, typical of 4-stroke engines. In such engines, in the valve overlap the phase pressure in the manifolds and the cylinder tend to equalize. A relatively low amount of internally re-circulated exhaust in the 4-stroke engine results in a negligible influence of this factor on the engine operation. In the case of HCCI engine with a negative valve overlap the internal EGR rate often exceeds the level of 0.6. The EGR rate is defined as the mass of the exhaust in relation to the whole in-cylinder fluid mass at the start of combustion (SOC):

$$
\mathrm{EGR}=\left(\frac{\mathrm{m}_{\mathrm{exh}}}{\mathrm{m}_{\mathrm{air}}+\mathrm{m}_{\mathrm{exh}}+\mathrm{m}_{\text {fuel }}}\right)_{\mathrm{cyl} \mathrm{soC}}
$$

The enthalpy of the trapped residuals increases the temperature of the fluid at the moment of intake valve closure (IVC). As a result, at the end of the compression stroke, in-cylinder conditions enable auto-ignition of the air-fuel mixture. In order to provide sufficient mass of the recirculated exhaust, closing of the exhaust valve takes place several dozen degrees of crank angle before top dead center (TDC). Thermodynamic parameters of the trapped residuals are determined by the combustion course [7]. The temperature of the residuals and resulting density determine the amount of fresh air that enters the cylinder and the rate of backflows $[10,14]$. Figure 1 presents the operating cycle of an HCCI engine with the internal exhaust re-circulation.

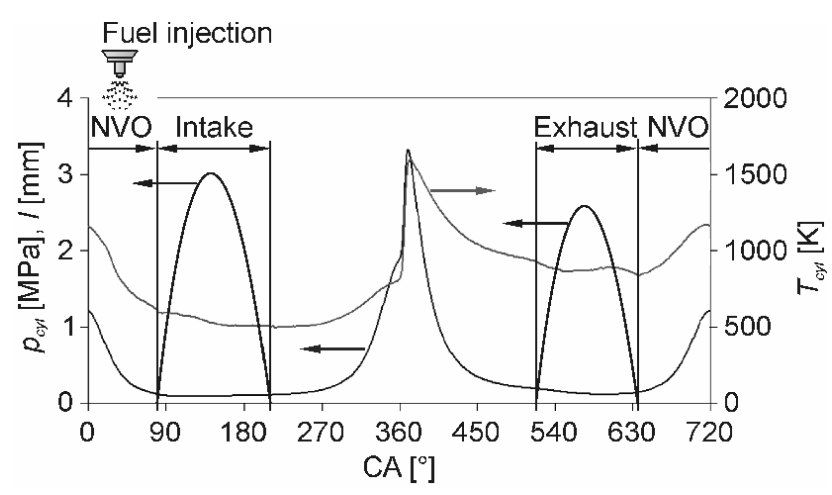

Fig. 1. In-cylinder pressure, temperature and valve lifts versus crank angle

Rys. 1. Ciśnienie i temperatura w cylindrze oraz wznios zaworów w funkcji kata obrotu watu korbowego

Backflows of the fluid to the intake system play an important role in the charge exchange process. This phenomenon can take place at the beginning (early backflow) and at the end (late backflow) of the intake process. Considering the fact that the fuel is injected during the NVO phase, backflows can cause variability of in-cylinder fuel mass and result in cycle-to-cycle changes of air excess coefficient. Both, early and late backflows are the reasons for the decrease of the engine thermal efficiency due to the pumping losses and heat exchange [6]. Moreover, the cooling effect of the backflows arrests the auto-ignition of the mixture [2]. aktywnego sterowania procesem wywiązywania się ciepła w cylindrze. Niniejszy artykuł jest kontynuacją poprzednich prac autora w tym zakresie $[4,5]$.

Przebieg procesu wymiany ładunku w silniku HCCI, pracującym z ujemnym współotwarciem zaworów, znacząco różni się od tych, realizowanych w klasycznych silnikach 4-suwowych. W typowych silnikach, w okresie współotwarcia zaworów wartości ciśnienia w cylindrze oraz kolektorach dolotowym i wylotowym dążą do wyrównania. Niewielka ilość wewnętrznie recyrkulowanych spalin w silniku 4-suwowym sprawia, że wywiera ona niewielki wpływ na przebieg procesu roboczego. W silniku HCCI z ujemnym współotwarciem zaworów współczynnik recyrkulacji często przekracza wartość 0,6 . Współczynnik ten wyrażony jest jako stosunek masy spalin do masy całego ładunku w cylindrze, w chwili poprzedzającej zapłon mieszanki - równanie (1).

Entalpia zatrzymanych w cylindrze spalin zwiększa temperaturę czynnika roboczego w chwili zamknięcia zaworu dolotowego, aby w końcowym etapie procesu sprężania umożliwić samozapłon mieszanki paliwowo-powietrznej. W celu zatrzymania w cylindrze odpowiednio dużej masy spalin, zamknięcie zaworu wylotowego następuje kilkadziesiąt stopni OWK przed górnym zwrotnym położeniem tłoka. Parametry termodynamiczne zatrzymywanych w cylindrze spalin kształtowane są przez przebieg procesu spalania [7]. Temperatura i wynikająca z niej gęstość spalin determinują ilość powietrza, która dostaje się do cylindra oraz ilość ładunku przepływającego z powrotem do kanału dolotowego podczas suwu dolotu $[10,14]$. Na rysunku 1 przedstawiono przebieg cyklu roboczego silnika HCCI z wewnętrzną recyrkulacją spalin.

Istotnym czynnikiem wpływającym na przebieg procesu wymiany ładunku są przepływy zwrotne do układu dolotowego, które mogą występować w początkowej lub końcowej fazie dolotu. Ze względu na to, że paliwo wtryskiwane jest do komory spalania w trakcie ujemnego współotwarcia zaworów, przepływy zwrotne pod koniec dolotu powodują również znaczne zmiany masy paliwa w cylindrze, co skutkuje zmiennością współczynnika nadmiaru powietrza. Oba rodzaje przepływów zwrotnych obniżają sprawność cieplną silnika ze względu na pracę pompowania oraz straty ciepła [6]. Ponadto chłodzący efekt tego procesu opóźnia chwilę samozapłonu [2]

\section{Stanowisko badawcze}

Badania eksperymentalne przeprowadzono na stanowisku z jednocylindrowym silnikiem badawczym. Dokładny opis budowy stanowiska znajduje się w publikacji [5]. Istotną cechą wykorzystanego silnika jest to, że poza zmodyfikowanym układem rozrządu jest to typowy benzynowy silnik o zapłonie iskrowym z tworzeniem mieszanki w cylindrze. Aby zrealizować badania procesu kontrolowanego samozapłonu na obiekcie jak najbardziej zbliżonym do rozwiązań technicznych znajdujących się w produkcji, a jednocześnie umożliwić sterowanie samozapłonem, w silniku badawczym zastosowano następujące rozwiązania:

a) niezależne sterowanie fazami rozrządu zaworu dolotowego i wylotowego, 


\section{Experimental test stand}

Experiments were conducted on a test stand with a single-cylinder research engine. Detailed description of the test stand can be found in ref. [5]. The most important feature of the engine was the fact that apart from the modified valvetrain mechanism, it is a typical spark ignition engine with direct fuel injection. In order to perform the research on the engine (the engine can be operated in the spark ignition combustion mode allowing a control of the auto-ignition) the following technical solutions were applied:

a) variable timing of inlet and exhaust valves,

b) fully variable valve lifts,

c) preheating of the intake charge using water jacket around the intake pipe,

d) gasoline direct injection.

Variable valve timing was achieved via a rotational shift of the camshafts against the toothed wheels. The valvetrain mechanism was equipped with a hydraulic device, which allowed a fluent regulation of active parts of the cams. The design of this device was described in detail in ref. [4]. Technical data of the test engine has been presented in Table 1. Figure 2 presents the range of achievable valve timings and lifts.

Table 1. Technical data of the research engine SB 3.5

Tabela 1. Dane techniczne silnika badawczego SB 3.5

\begin{tabular}{|l|c|}
\hline Displacement/pojemność & $498.5 \mathrm{~cm}^{3}$ \\
\hline Bore/średnica tłoka & $84 \mathrm{~mm}$ \\
\hline Stroke/skok tłoka & $90 \mathrm{~mm}$ \\
\hline Compression ratio/stopień sprężania & 11.7 \\
\hline No. of valves/liczba zaworów & 2 \\
\hline Fuel injector/wtryskiwacz & Solenoid actuated swirl type \\
\hline Fuel pressure/ciśnienie wtrysku & $9.6 \mathrm{MPa}$ \\
\hline Fuel/paliwo & Gasoline 95 RON \\
\hline
\end{tabular}

\section{Determination of the internal EGR rate}

In engines with external EGR the amount of re-circulated gas is estimated via simultaneous measurement of the $\mathrm{CO} 2$ content in the exhaust and the intake manifolds [1]. The problem while determining the EGR rate in an engine with exhaust gas trapping is that the mixing takes place inside the cylinder.

The assessment of the trapped residual mass can be done with the use of indirect method. If the in-cylinder pressure and the temperature are known, mass can be calculated with the use of the ideal gas equation of state. However, direct measurement of the instantaneous temperature inside the cylinder is very difficult in practice. Fluid temperature at the exhaust valve closure (EVC) can also be provided by the temperature measurement in the exhaust port. This approach is often used for the assessment of the trapped residual amount [8]. Mass of the re-circulated exhaust can be calculated from the following equation:

$$
\mathrm{m}_{\text {exh,cyl,EVC }}=\frac{\mathbf{p}_{\text {cyl,EVC }} V_{\text {cyl,EVC }}}{R_{\text {exh }} T_{\text {exh }}}
$$

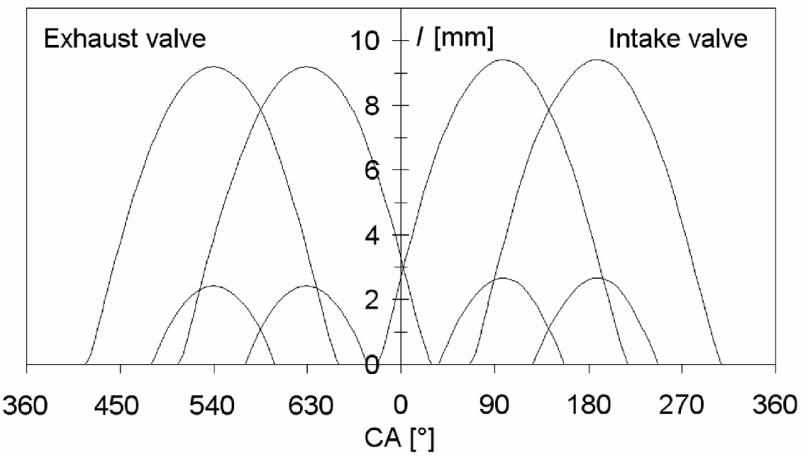

Fig. 2. The range of achievable valve timings and lifts Rys. 2. Zakres zmian faz rozrządu i wzniosu zaworów

b) niezależne, płynne sterowanie wzniosem zaworów,

c) ogrzewanie powietrza dolotowego jedynie przez płaszcz wodny połączony z układem chłodzenia silnika,

d) bezpośredni wtrysk benzyny.

Regulację faz rozrządu zrealizowano przez obracanie wałów rozrządu względem kół zębatych, natomiast zmianę wzniosu zaworów uzyskano za pomocą mechanizmu hydraulicznego. Budowę tego mechanizmu przedstawiono szczegółowo w innej pracy autora [4]. Dane techniczne silnika badawczego przedstawiono w tabeli 1 . Na rysunku 2 przedstawiono zakres zmian wzniosu zaworów i faz rozrządu, jaki można uzyskać w silniku badawczym.

\section{Określanie współczynnika wewnętrznej recyrkulacji spalin}

W silnikach z zewnętrzną recyrkulacją spalin do oceny ilości spalin najczęściej wykorzystywane są pomiary stężenia $\mathrm{CO}_{2} \mathrm{w}$ układzie dolotowym [1]. Problem określania współczynnika EGR w silniku z ujemnym współotwarciem zaworów polega na tym, że proces mieszania powietrza $\mathrm{i}$ spalin odbywa się w cylindrze.

Ocena masy spalin w cylindrze może być także dokonana z wykorzystaniem metody pośredniej. Dysponując wartością ciśnienia oraz temperatury w komorze spalania w chwili zamykania zaworu wylotowego, możliwe jest określenie masy spalin na podstawie równania stanu gazu - równanie (2). Pomiar chwilowych wartości temperatury w cylindrze jest jednak trudny w praktycznej realizacji, dlatego można tu wykorzystać wyniki pomiarów temperatury wykonywanych w kanale wylotowym możliwie blisko zaworu. Praktyka ta jest często stosowana przy określaniu masy spalin pozostałych w cylindrze [8].

Powyższa metoda szacowania masy spalin została zweryfikowana przez Wildmana i in. [11]. Na rysunku 3 przedstawiono wyniki obliczeń stopnia recyrkulacji spalin metodą bezpośrednią oraz metodą pośrednią, według równania (2). Przy zastosowaniu metody bezpośredniej czynnik roboczy był pobierany bezpośrednio z cylindra.

Należy jednak pamiętać, że tak obliczona wartość nie jest masą spalin recyrkulowanych w kolejnym cyklu pracy silnika. Na skutek przepływów zwrotnych podczas procesu dolotu część spalin pozostanie w kolektorze dolotowym, 
This method was verified by Wildman et al. [11]. Figure 3 presents in-cylinder residual fraction calculated based on the $\mathrm{CO}_{2}$ balance and using equation (2). The in-cylinder $\mathrm{CO}_{2}$ content was measured with the use of cylinder fluid sampling probe.

It is noteworthy that the calculated mass of the exhaust trapped in a single engine operation cycle is not equal to the re-circulated mass in the following cycle. Because of the backflows, during the intake stroke some amount of exhaust will flow into the intake port, while the residuals existing in the intake system will enter the cylinder.

\section{Charge exchange model}

The information about the volumetric efficiency and EGR rate is insufficient in the analysis of the working cycle of an HCCI engine operated in the NVO mode. In order to define thermodynamic properties of the in-cylinder fluid the whole charge exchange process should be known.

An elaborated hybrid model uses the results of the indicated pressure measurements as one of the boundary conditions. The mixture properties in the intake manifold are calculated based on the mass flow of the medium through the throttle and the intake valve and the heat exchange with the walls of the intake system. The aim of modeling was not to substitute the measurements with the simulated data but to support the experimental data analysis. Considering

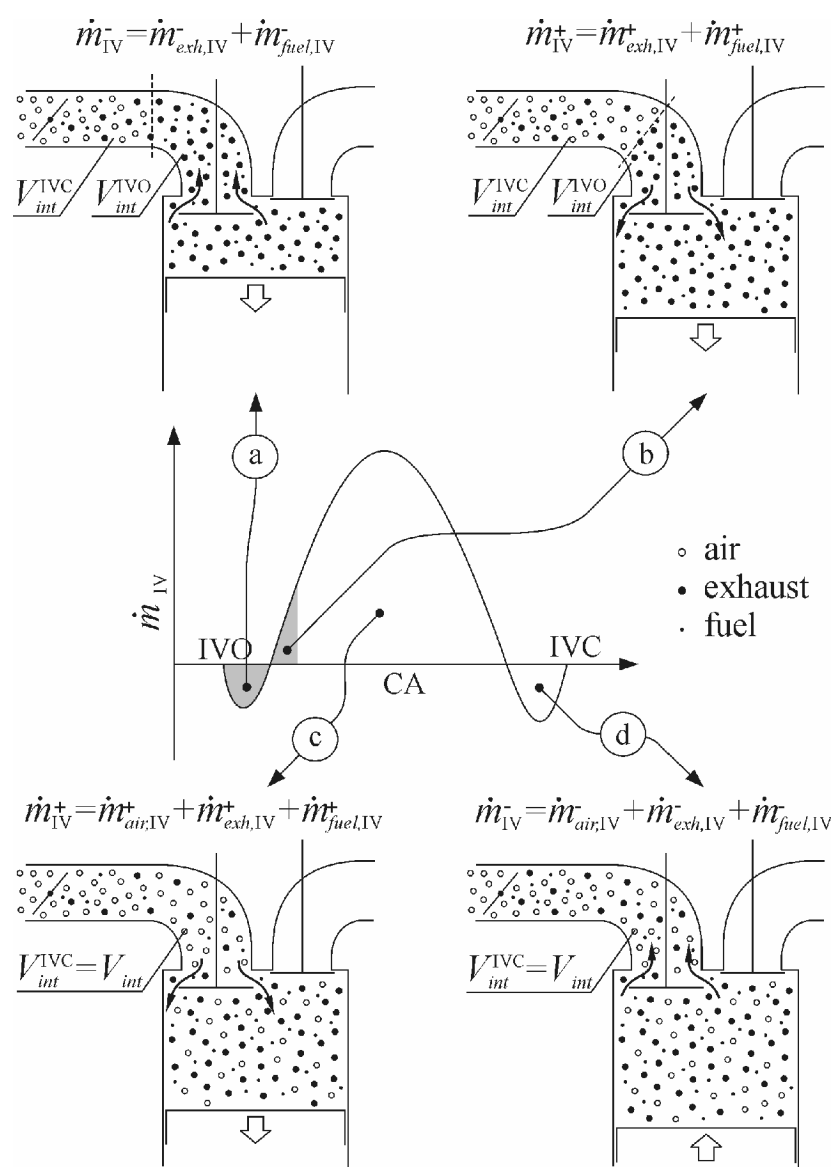

Fig. 4. Schematic presentation of the mass balance during the intake process

Rys. 4. Schematyczna prezentacja bilansu masy podczas procesu dolotu

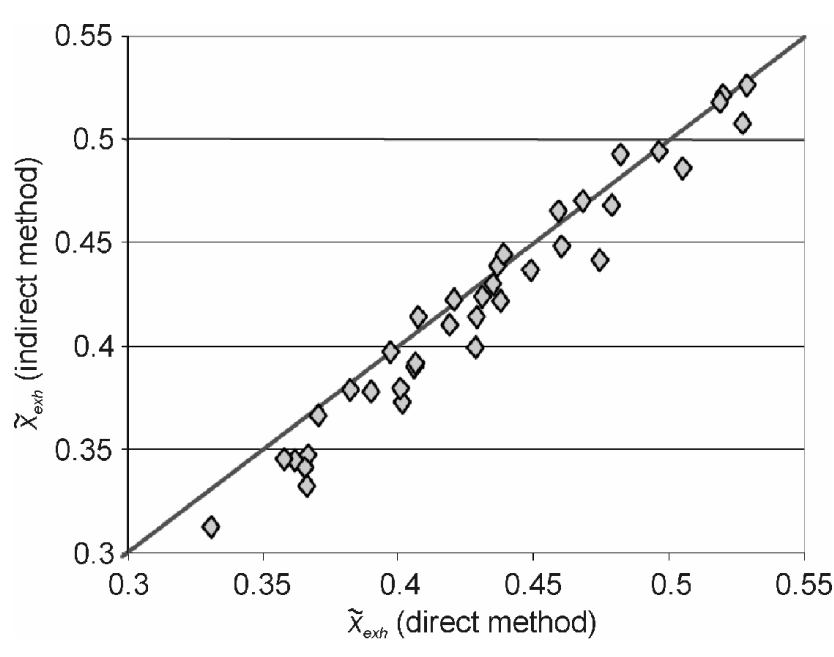

Fig. 3. The comparison of the exhaust molar fractions measured with the use of in-cylinder gas sampling system (direct method) and calculated from the ideal gas equation of state at the EVC (indirect method) [11]

Rys. 3. Porównanie frakcji molowych spalin $w$ cylindrze określonych przez pomiar składu czynnika (metoda bezpośrednia) oraz obliczonych z równania stanu gazu (metoda pośrednia) [11]

natomiast część masy spalin znajdujących się w kolektorze dolotowym napłynie do cylindra.

\section{Model wymiany ladunku}

Aby przeprowadzić analizę procesu roboczego silnika HCCI, pracującego z ujemnym współotwarciem zaworów, nie wystarczy znajomość wyłącznie współczynnika napełnienia oraz współczynnika recyrkulacji spalin. W celu określenia parametrów termodynamicznych czynnika konieczna jest znajomość przebiegu wymiany ładunku.

Opracowany model hybrydowy wykorzystuje przebieg ciśnienia w cylindrze pochodzący z pomiarów. Parametry termodynamiczne czynnika w kolektorze dolotowym są obliczane na podstawie masy napływającego i wypływającego czynnika oraz ciepła wymienianego pomiędzy czynnikiem i ściankami rury dolotowej. Celem modelowania było wspomaganie analizy wyników badań eksperymentalnych, a nie odtworzenie przebiegu całego cyklu roboczego. W związku z tym uznano, że wystarczający będzie 1-wymiarowy model, powszechnie wykorzystywany w tego typu aplikacjach $[9,10]$. Ze względu na znaczące różnice pomiędzy procesami zachodzącymi w typowych silnikach czterosuwowych a silnikiem o kontrolowanym samozapłonie, w proponowanym modelu dokonano podziału objętości kontrolnej układu dolotowego na strefy. Zależnie od rodzaju przepływów zwrotnych spaliny i paliwo zawrócone do układu dolotowego mogą się mieszać lub nie mieszać z powietrzem.

Proces wymiany ładunku podzielono na 4 etapy (rys. 4): a) przepływ zwrotny mieszaniny spalin z paliwem do kolektora dolotowego,

b) wlot do cylindra spalin i paliwa, które wypłynęły we wczesnej fazie dolotu,

c) napływ do cylindra powietrza wraz z częścią spalin i paliwa, które wypłynęły z cylindra w poprzednich cyklach pod koniec procesu dolotu, 
that, a one-dimensional model was applied, which is widely used for data analysis or model-based engine control [9, 10]. Due to fundamental differences between the charge exchange process in classic 4-stroke engines and controlled auto-ignition engines, the intake duct was divided into two control volumes. Depending on the kind of backflows (early or late), the mixture of the exhaust and the fuel vapor can be isolated from the rest of the intake pipe or its whole content can create homogeneous mixture.

The intake process was divided into 4 stages (Fig. 4):

a) backflow of the exhaust and the fuel mixture from the cylinder to the intake port (early backflow),

b) flow of the exhaust and the fuel mixture into the cylinder,

c) flow of fresh air and the mass of late backflow from the previous cycle,

d) backflow of fresh air, the exhaust and the fuel before IVC (late backflow).

The course of the intake process depends on the valve timings and lifts, rotational speed and thermodynamic properties of the in-cylinder charge. At a relatively retarded intake valve timing, processes (c) and (d) take place. At early IVO processes (a), (b) and (c), or all of them are observed.

\section{Experimental results and data analysis}

\subsection{Experimental conditions}

The experiment was conducted at constant engine speed of $1500 \mathrm{rev} / \mathrm{min}$ and a constant throttle ( $37 \mathrm{~mm}$ diameter) position of $50 \%$. The temperature of the coolant was constant and set to $87^{\circ} \mathrm{C}$. The engine was naturally aspirated. The average temperature in the intake pipe was approximately $40{ }^{\circ} \mathrm{C}$, however it was affected by the backflow effect. The fuel was injected in the NVO stage, during the exhaust expansion process. Both valve timings and lifts were varied. The test at variable air excess coefficient $(\lambda)$ was also conducted. All experiments were performed at engine operated in the autonomous HCCI mode (with ignition system switched off).

\subsection{Charge exchange process}

The mass flow rate of the fluid through the intake valve at variable valve timings is presented in Figure 5. At a retarded EVC the mass of the exhaust and the fuel before the commencement of the intake process was approximately $150 \mathrm{mg}$, while at an advanced EVC it was about $190 \mathrm{mg}$. Also, it should be noted that at late IVO the in-cylinder mass is insignificantly higher. It is related to a lower exhaust temperature (higher density) due to the cooling effect of the backflows.

The maximum mass flow rate and the amount of intake mass are dependent on the exhaust valve timing rather than on the intake valve phases (Fig. 5). Such a significant influence of the EVC event on the mass of the fresh charge is a result of a large amount of trapped residuals. The intake process in the engine operated in the NVO mode takes place at much higher temperatures than in typical 4-stroke SI engines. Heating up of fresh air, which determines the mass flow rate, is dependent on the enthalpy of the re-circulated d) przepływ zwrotny mieszaniny powietrza, spalin i paliwa do kolektora dolotowego na końcowym etapie dolotu.

Zależnie od faz rozrządu, wzniosu zaworów, prędkości obrotowej wału korbowego silnika oraz parametrów termodynamicznych czynnika roboczego w cylindrze mogą zachodzić różne warianty przepływu czynnika. Przy względnie późnych otwarciach zaworu dolotowego występują tylko etapy c i d, natomiast przy wczesnych otwarciach - procesy opisane w punktach a, b i c lub wszystkie z nich.

\section{Analiza wyników badań eksperymentalnych}

\subsection{Warunki badań}

Badania eksperymantalne przeprowadzono przy stałej prędkości obrotowej wynoszącej $1500 \mathrm{obr} / \mathrm{min}$ oraz stałym otwarciu przepustnicy (o średnicy $37 \mathrm{~mm}$ ) wynoszącym $50 \%$. Temperatura cieczy chłodzącej była stała i wynosiła $87^{\circ} \mathrm{C}$. Silnik pracował jako wolnossący przy temperaturze dolotu na poziomie $40^{\circ} \mathrm{C}$. Należy jednak zauważyć, że temperatura dolotu zmieniała się zależnie od natężenia przepływów zwrotnych. Paliwo wtryskiwane było do cylindra podczas rozprężania spalin w fazie ujemnego współotwarcia zaworów. Podczas eksperymentów zmieniano fazy rozrządu, wznios zaworów oraz współczynnik nadmiaru powietrza $(\lambda)$. Wszystkie badania wykonano przy autonomicznej pracy silnika w trybie HCCI, z wyłączonym układem zapłonowym.

\subsection{Przebieg procesu wymiany ladunku}

Na rysunku 5 przedstawiono strumień masy ładunku przepływającego przez zawór dolotowy dla różnych kombinacji faz zaworu dolotowego i wylotowego. Przy późnym zamknięciu zaworu wylotowego masa spalin i paliwa $\mathrm{w}$ cylindrze przed rozpoczęciem procesu dolotu wynosiła $150 \mathrm{mg}$, natomiast przy wczesnym zamknięciu wzrastała do $190 \mathrm{mg}$. Masa czynnika była nieznacznie większa przy późnym otwarciu zaworu dolotowego. Wynika to z mniej-

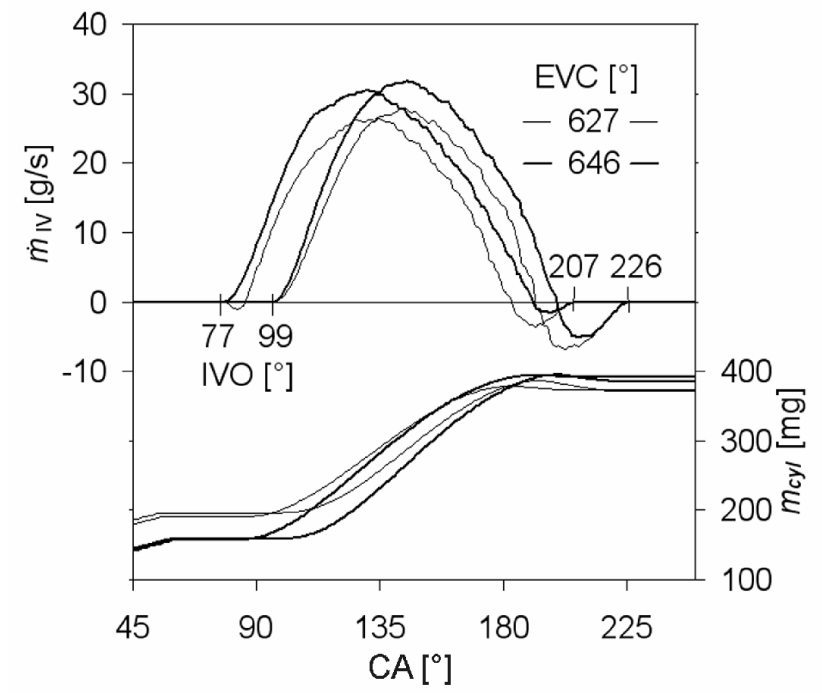

Fig. 5. The mass flow through the intake valve at variable valve timings;

$$
1_{\mathrm{IV}}=3.6 \mathrm{~mm}, 1_{\mathrm{EV}}=2.9 \mathrm{~mm}, \lambda=1.08
$$

Rys. 5. Strumień masy przeplywającej przez zawór dolotowy dla zmiennych faz rozrzadu; $l_{I V}=3,6 \mathrm{~mm}, l_{E V}=2,9 \mathrm{~mm}, \lambda=1,08$ 
exhaust. At the same time, the cooling effect of fresh air causes a decrease in the specific volume of the residuals. Considering the above, the volumetric efficiency will be larger where the exhaust gas has a higher temperature and a lower specific heat (lower content of $\mathrm{CO}_{2}$ and $\mathrm{H}_{2} \mathrm{O}$ ).

\subsection{Charge exchange at variable valvetrain settings}

In the author's previous work [5] it was stated that the volumetric efficiency is dependent on the intake valve timings to a very limited extent. The delay of the intake valve timing insignificantly decreases the fresh charge mass, mainly due to late backflows at the end of the intake. Figure 6 presents the volumetric efficiency and EGR rate at variable timings and lifts of the exhaust valve. The lift of the intake valve was set to $3.6 \mathrm{~mm}$, IVO and IVC took place at $83{ }^{\circ} \mathrm{CA}$ and $213^{\circ} \mathrm{CA}$ respectively. Air excess coefficient $(\lambda)$ was constant and equaled to 1.08 .

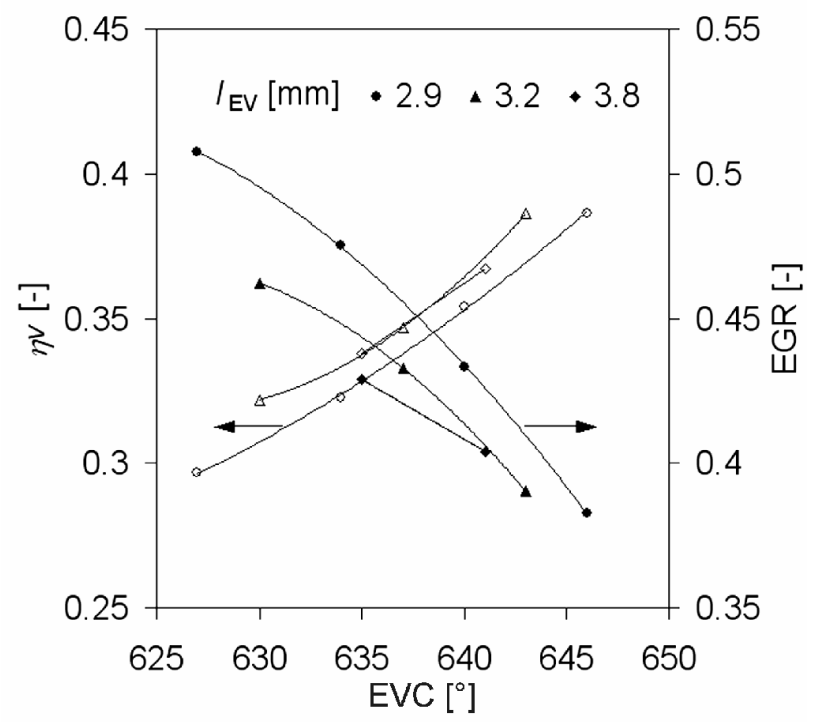

Fig. 6. The volumetric efficiency and EGR rate at variable timing and lift of the exhaust valve; $1_{\mathrm{IV}}=3.6 \mathrm{~mm}, 1_{\mathrm{vo}}=83{ }^{\circ} \mathrm{CA}, \lambda=1.08$

Rys. 6. Wspótczynnik napetnienia oraz współczynnik recyrkulacji spalin $w$ funkcji kąta zamknięcia i wzniosu zaworu wylotowego; $l_{I V}=3,6 \mathrm{~mm}$, $l_{\text {Vo }}=83^{\circ} \mathrm{OWK}, \lambda=1,08$

In the case of the exhaust valve lift $1_{\mathrm{EV}}=2.9 \mathrm{~mm}$, in the range of valve timings at which the engine was able to run in the auto-ignition mode, the volumetric efficiency was varied between 0.29 and 0.38 , while the EGR rate was varied from 0.51 to 0.38 . It allowed obtaining an indicated mean effective pressure (IMEP) in the range from $0.24 \mathrm{MPa}$ to 0.35 $\mathrm{MPa}$. The increase of exhaust valve lift to $3.2 \mathrm{~mm}$ decreased amount of the re-circulated exhaust and gave a higher volumetric efficiency (Fig. 6). At earlier EVC the influence of the exhaust valve lift is more noticeable. A further increase in the valve lift does not affect the EGR rate and the volumetric efficiency. It is a result of the fact that the volume of the exhaust is relatively low and even a reduced lift of the valve allows equalizing the pressures at both sides of the valve. Moreover, an advance of EVO and the resulting decrease in the thermodynamic expansion ratio results in a drop of szej temperatury spalin, ze względu na chłodzące działanie przepływów zwrotnych.

Maksymalne wartości natężenia przepływu, jak również masa ładunku w cylindrze po zakończeniu procesu napełniania cylindra w większym stopniu zależą od faz zaworu wylotowego niż zaworu dolotowego. Tak istotny wpływ fazy zaworu wylotowego na proces napełniania wynika z dużej ilości pozostałych w cylindrze spalin. Proces dolotu w silniku z ujemnym współotwarciem zaworów odbywa się w znacznie wyższych temperaturach niż w typowych silnikach 4-suwowych. Ogrzewanie i rozprężanie powietrza w cylindrze zależne jest od entalpii pozostałych spalin. Jednocześnie, na skutek chłodzenia spalin podczas dolotu, zmniejsza się ich objętość właściwa. Wynika stąd, że większe napełnienia cylindra będą uzyskiwane przy większych temperaturach spalin o mniejszym cieple właściwym (o mniejszej zawartości $\mathrm{CO}_{2} \mathrm{i}_{2} \mathrm{O}$ ).

\subsection{Wymiana ladunku przy zmiennych fazach rozrzą- du i wzniosie zaworów}

W pracy autora [5] wykazano, że napełnienie cylindra w nieznacznym stopniu zależy od faz zaworu dolotowego. Opóźnianie faz zaworu dolotowego w bardzo niewielkim stopniu zmniejsza współczynnik napełnienia cylindra, głównie ze względu na przepływy zwrotne w końcowej fazie procesu dolotu. Na rysunku 6 przedstawiono współczynnik napełnienia cylindra i współczynnik recyrkulacji spalin przy zmiennych fazach i wzniosach zaworu wylotowego. Wznios zaworu dolotowego wynosił 3,6 mm, kąt otwarcia $83^{\circ} \mathrm{OWK}$, a kąt zamknięcia $213{ }^{\circ} \mathrm{OWK}$. Współczynnik nadmiaru powietrza $\lambda$ wynosił 1,08 .

Przy wzniosie zaworu wylotowego $1_{\mathrm{EV}}=2,9 \mathrm{~mm}$, w zakresie faz, przy których silnik jest w stanie pracować współczynnik napełnienia zmieniał się od około 0,29 do około 0,38 , podczas gdy współczynnik recyrkulacji spalin zmieniał się w granicach $0,51 \ldots 0,38$. Pozwoliło to na zmianę średniego ciśnienia indykowanego w zakresie od 0,24 $\mathrm{MPa}$ do $0,35 \mathrm{MPa}$. Zwiększenie wzniosu zaworu wylotowego do 3,2 mm zmniejsza ilość recyrkulowanych wewnętrznie spalin, powodując jednocześnie większe napełnienie cylindra świeżym powietrzem (rys. 6). Przy wczesnych kątach zamknięcia zaworu wylotowego wpływ wzniosu zaworu jest bardziej widoczny. Dalsze zwiększanie wzniosu zaworu wylotowego nie powoduje znacznych zmian napełnienia ani ilości zatrzymywanych spalin. Wynika to z faktu, że objętość spalin opuszczających cylinder jest względnie mała $i$ nawet znacznie zredukowany wznios zaworu wylotowego pozwala na wyrównanie się ciśnień w cylindrze i w kolektorze wylotowym. Zbytnie wyprzedzenie otwarcia zaworu wylotowego i wynikające $\mathrm{z}$ tego zmniejszenie termodynamicznego stopnia rozprężania skutkuje obniżeniem pracy indykowanej w cylindrze. Poza tym taki sam skutek (ilość recyrkulowanych spalin) można osiągnąć przez niewielką zmianę faz rozrządu. $Z$ technicznego punktu widzenia drugi sposób jest znacznie korzystniejszy.

W sytuacji zwiększenia wzniosu zaworu dolotowego (do 4,2 mm) nie zaobserwowano wzrostu współczynnika napełnienia cylindra ze względu na wzrastające natężenie 
the engine thermal efficiency. The same result (amount of re-circulated exhaust) can be obtained via relatively small change of valve timing. From the technical point of view, the second approach is much more feasible.

In the case of higher intake valve lift $(4.2 \mathrm{~mm})$ the authors did not observe a substantial increase in the volumetric efficiency. Larger flow rates through the valve were compensated by rising backflow rates. At the same the IVO timing $\left(83^{\circ} \mathrm{CA}\right)$ due to a valve lift and the IVC timing were retarded from $213{ }^{\circ} \mathrm{CA}$ to $223^{\circ} \mathrm{CA}$.

It should be noted that there was a balance between amounts of fresh air and residuals, which results in an almost constant entire in-cylinder fluid mass.

\subsection{Charge exchange at variable air excess coefficient}

In order to enable an extensive engine load regulation, there is a need to combine variable valve timings with variable air excess coefficient [12]. The air excess coefficient determines the in-cylinder temperature. Furthermore, the exhaust density influences the amount of fresh air that flows into the cylinder. Due to a very strong relationship between the air excess coefficient and the volumetric efficiency another mixture strength coefficient was introduced - mixture dilution coefficient, defined as:

$$
\psi=\frac{\mathrm{m}_{\text {air }}+\mathrm{m}_{\text {exh }}}{\mathrm{m}_{\text {fuel }}}
$$

The mixture dilution $\psi$ is a ratio of the in-cylinder mass (fresh air and re-circulated exhaust) and the mass of fuel. Figure 7 presents the relationship between the air excess coefficient and the internal EGR ratio at variable NVO crank angles. Valve lifts were constant $\left(1_{\mathrm{IV}}=3.6 \mathrm{~mm}, 1_{\mathrm{EV}}=2.9\right.$ $\mathrm{mm}$ ). In the case of each NVO, the valve timings were set to obtain a maximum thermal efficiency of the engine [5]. Additionally, maximum achievable mixture dilution ratios were presented. A combination of variable valve timings and the air excess coefficient allowed a regulation of the IMEP from $0.17 \mathrm{MPa}$ to $0.36 \mathrm{MPa}$.

The highest range of the air excess coefficient was achieved at $\mathrm{NVO}$ angle equal to $173{ }^{\circ} \mathrm{CA}$. Both the increase and the decrease in the engine load by valvetrain settings result in a limitation of the stable operating range. However, the maximum mixture dilution coefficient increases with the increasing NVO angle.

In general, at increasing the air excess coefficient the engine output drops much more than the one resulting from a merely lower fuel demand. Leaner mixtures cause a drop in the exhaust temperatures, which increases the internal EGR rate and decreases the amount of fresh air introduced into the cylinder.

\subsection{Variability of in-cylinder mass}

In the whole range of engine operation there is a balance between the in-cylinder fluid thermodynamic properties, the mass of the re-circulated exhaust and the mass of fresh air. The volumetric efficiency, the exhaust temperature and the EGR rate are strongly correlated, resulting in an almost constant overall in-cylinder mass. At suitable valvetrain settings przepływów zwrotnych. Przy takiej samej fazie otwarcia wynoszącej $83^{\circ} \mathrm{OWK}$, na skutek wzrostu wzniosu zaworu, faza zamknięcia zwiększyła się z $213{ }^{\circ} \mathrm{OWK}$ do $223^{\circ} \mathrm{OWK}$.

Należy zauważyć, że występuje pewna równowaga pomiędzy ilością powietrza i recyrkulowanych spalin w cylindrze. W związku z tym masa ładunku jest stała.

\subsection{Wymiana ladunku przy zmiennym współczynniku nadmiaru powietrza}

Aby możliwa była regulacja obciążenia silnika w szerokim zakresie konieczne jest połączenie zmiennych faz rozrządu i zmiennego współczynnika nadmiaru powietrza [12]. Współczynnik nadmiaru powietrza determinuje temperaturę w cylindrze. Wynikająca z tego gęstość spalin wpływa na ilość powietrza, jaka napłynie do cylindra. Ze względu na tak istotny związek pomiędzy współczynnikiem nadmiaru powietrza a współczynnikiem recyrkulacji spalin, wprowadzono dodatkowy współczynnik składu mieszanki wyrażający stopień rozrzedzenia ładunku w cylindrze - równanie (3). Współczynnik rozrzedzenia ładunku $\psi$ wyraża stosunek łącznej masy powietrza i spalin do masy paliwa w cylindrze. Na rysunku 7 przedstawiono zależność współczynnika recyrkulacji spalin od współczynnika nadmiaru powietrza przy różnych kątach ujemnego współotwarcia zaworów. Wzniosy zaworów były stałe $\left(1_{\mathrm{IV}}=3,6 \mathrm{~mm}, 1_{\mathrm{EV}}=2,9 \mathrm{~mm}\right)$. Przy każdym kącie ujemnego współotwarcia zaworów fazy rozrządu były ustawione tak, aby uzyskać największą sprawność cieplną silnika [5]. Dodatkowo oznaczono maksymalne, osiągalne wartości współczynnika rozrzedzenia ładunku. Połączenie regulacji faz rozrządu i współczynnika nadmiaru powietrza pozwoliło na uzyskiwanie średniego ciśnienia indykowanego w zakresie od 0,17 MPa do 0,36 MPa.

Największy zakres współczynnika nadmiaru powietrza osiągany jest przy kącie ujemnego współotwarcia zaworów

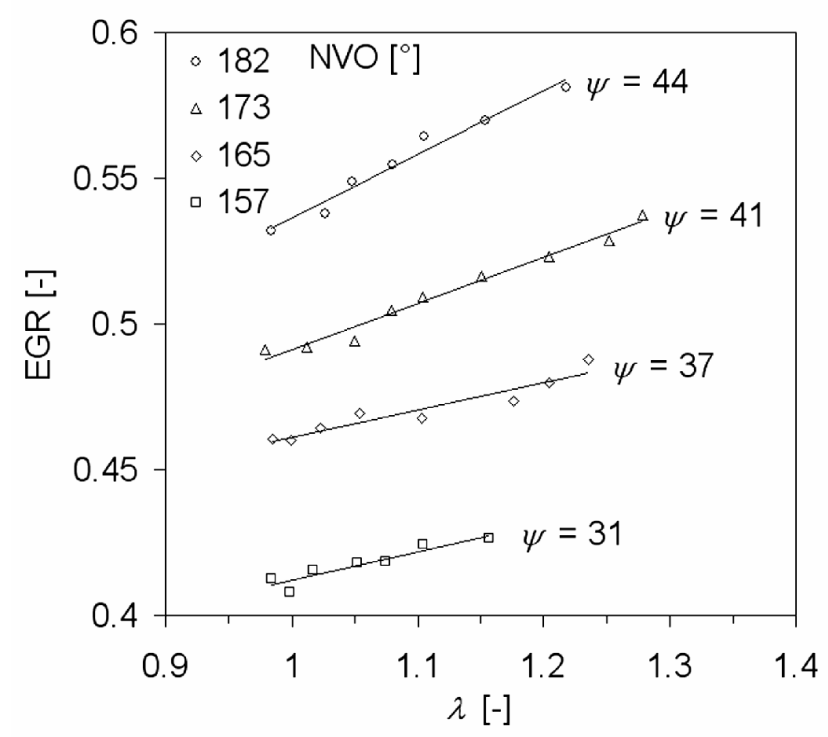

Fig. 7. Internal EGR rate versus air excess coefficient $(\lambda)$ at variable NVO crank angle; $1_{\mathrm{IV}}=3.6 \mathrm{~mm}, 1_{\mathrm{EV}}=2.9 \mathrm{~mm}$

Rys. 7. Współczynnik recyrkulacji spalin w funkcji wspótczynnika nadmiaru powietrza przy zmiennych kątach ujemnego współotwarcia zaworów; $l_{I V}=3,6 \mathrm{~mm}, l_{E V}=2,9 \mathrm{~mm}$ 


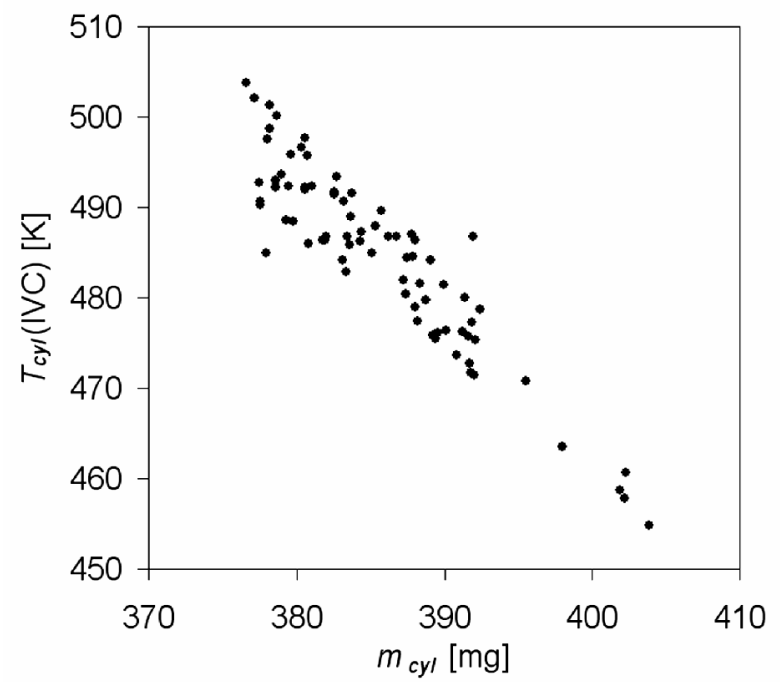

Fig. 8. The in-cylinder temperature at IVC versus in-cylinder mass at various engine loads

Rys. 8. Zależność temperatury początku sprężania od masy ładunku w cylindrze przy zmiennych obciażeniach silnika

the thermodynamic properties related to the charge exchange provide an appropriate temperature-volume compression course, which is independent of the air excess coefficient or the volumetric efficiency.

Figure 8 presents the in-cylinder temperature at the beginning of the compression against the overall fluid mass in the cylinder. In the analyzed range of engine operation the in-cylinder mass, related to the air mass that would fill the whole cylinder volume at normal physical conditions was varied in the range of only $4 \%$, while the temperature at IVC was varied in the range of $50 \mathrm{~K}$.

The increase in the charge temperature at lower fluid mass is compensated by a larger share of the heat losses during compression. As a result, the auto-ignition temperature is always achieved at the appropriate crank angle. The auto-ignition temperature itself is also nearly constant (approximately $775 \mathrm{~K}$ ). This value insignificantly increases with the rising mixture dilution coefficient.

\subsection{Cycle-to-cycle variability}

The above-presented mechanism, which guarantees a correct course of the compression temperature, also provides a stable engine operation. The relationship between the in-cylinder conditions and the heat release rate parameters provides a stable engine operation without the need of active closed-loop engine control. The combustion onset and the heat release rate are determined by the air-excess coefficient, the EGR rate and the backflow rate, which decreases the temperature at the start of the compression. Figure 9 presents the courses of in cylinder temperature for consecutive cycles.

Figure 10 presents the values that define the crank angle combustion course and the charge exchange process for consecutive engine cycles. The engine was operated at a lean mixture. The coefficient of variation in the IMEP was approximately 0.08 . The backflow rate was a ratio of fluid mass that flowed from the cylinder to the intake port during równym $173{ }^{\circ} \mathrm{OWK}$. Zarówno zmniejszanie, jak i zwiększanie masy spalin w cylindrze powoduje ograniczenie nadmiaru powietrza, pozwalającego na stabilną pracę silnika. Jednakże sam graniczny stopień rozrzedzenia ładunku wzrasta przy zwiększaniu ilości recyrkulowanych spalin.

Generalnie przy zwiększaniu współczynnika $\lambda$ obciążenie silnika maleje znacznie szybciej, niż wynikałoby to z samego współczynnika nadmiaru powietrza. Zubażanie mieszanki prowadzi do zwiększenia gęstości spalin, a w konsekwencji maleje napełnienie cylindra.

\subsection{Zmienność masy ladunku w cylindrze}

W całym zakresie obciążenia występuje pewien stan równowagi pomiędzy parametrami termodynamicznymi czynnika zasysanego i opuszczającego cylinder. Współczynnik napełnienia cylindra, temperatura spalin i współczynnik recyrkulacji spalin są ze sobą ściśle związane, a łączna masa ładunku w cylindrze zmienia się w bardzo niewielkim stopniu. Przy właściwych nastawach układu rozrządu procesy termodynamiczne związane z wymianą ładunku gwarantują utrzymanie właściwego przebiegu krzywej temperatury sprężania, niezależnie od współczynnika nadmiaru powietrza i współczynnika napełnienia cylindra.

Na rysunku 8 przedstawiono temperaturę w cylindrze na początku sprężania w funkcji masy czynnika roboczego. $\mathrm{W}$ analizowanym zakresie pracy silnika masa czynnika $\mathrm{w}$ cylindrze w stosunku do masy powietrza, jaka znajdowałaby się w objętości skokowej cylindra przy współczynniku napełnienia równym jedności, zmienia się zaledwie o 4\%, a temperatura w chwili zamknięcia zaworu dolotowego - o 50 $\mathrm{K}$. Zwiększenie temperatury przy małych masach ładunku kompensowane jest większym udziałem strat ciepła. W wyniku tego temperatura samozapłonu zawsze uzyskiwana jest przy właściwym położeniu wału korbowego. Sama wartość temperatury samozapłonu również jest prawie stała (około $775 \mathrm{~K}$ ) i nieznacznie wzrasta wraz z rozrzedzeniem ładunku.

\subsection{Zmienność cykliczna procesu roboczego}

Opisany powyżej mechanizm zapewniający właściwy przebieg temperatury sprężania w warunkach zmiennego obciążenia zapewnia także powtarzalną pracę silnika. Wzajemne relacje pomiędzy warunkami panującymi w komorze spalania oraz podstawowymi wielkościami związanymi z kątowym przebiegiem spalania utrzymują stabilną pracę silnika bez konieczności aktywnego sterowania procesem wywiązywania się ciepła. Wielkości, które determinują chwilę samozapłonu oraz długość procesu spalania to współczynnik nadmiaru powietrza, współczynnik recyrkulacji spalin oraz natężenie przepływów zwrotnych do kanału dolotowego, które ochładzają czynnik w komorze spalania. Na rysunku 9 przedstawiono przebiegi temperatury w cylindrze w kolejnych cyklach pracy silnika.

Na rysunku 10 przedstawiono wartości podstawowych wielkości opisujących przebieg wymiany ładunku oraz wielkości charakteryzujących przebieg spalania w kolejnych cyklach pracy silnika. Współczynnik zmienności średniego ciśnienia indykowanego wynosił 0,08. Jako współczynnik wyrażający intensywność przepływów zwrotnych przyj- 
the intake process (early and late backflows) and the entire in-cylinder mass after IVC.

The amount of fresh air that enters the cylinder is dependent on the mass of the trapped exhaust. As a result the temperature during the exhaust process is a factor determining the course of the compression and the start of the combustion in the engine cycle that follows.

A rapid heat release rate causes a decrease in the exhaust temperature. A higher exhaust density results in a lower volumetric efficiency and a slower combustion in the cycle that follows.

As the fuel is injected directly into the cylinder, this process does not vary the mass of fuel. However, the variability of the air excess coefficient decreases the changes in the combustion rate, which is a result of the variable mass of air.

\section{Conclusions}

Residual-effected gasoline HCCI engines can be operated in a wide range of loads without the need of active, closed-loop control of the combustion onset and the rate of heat release. A proper course of the compression temperature that ensures auto-ignition close to TDC is a result of the
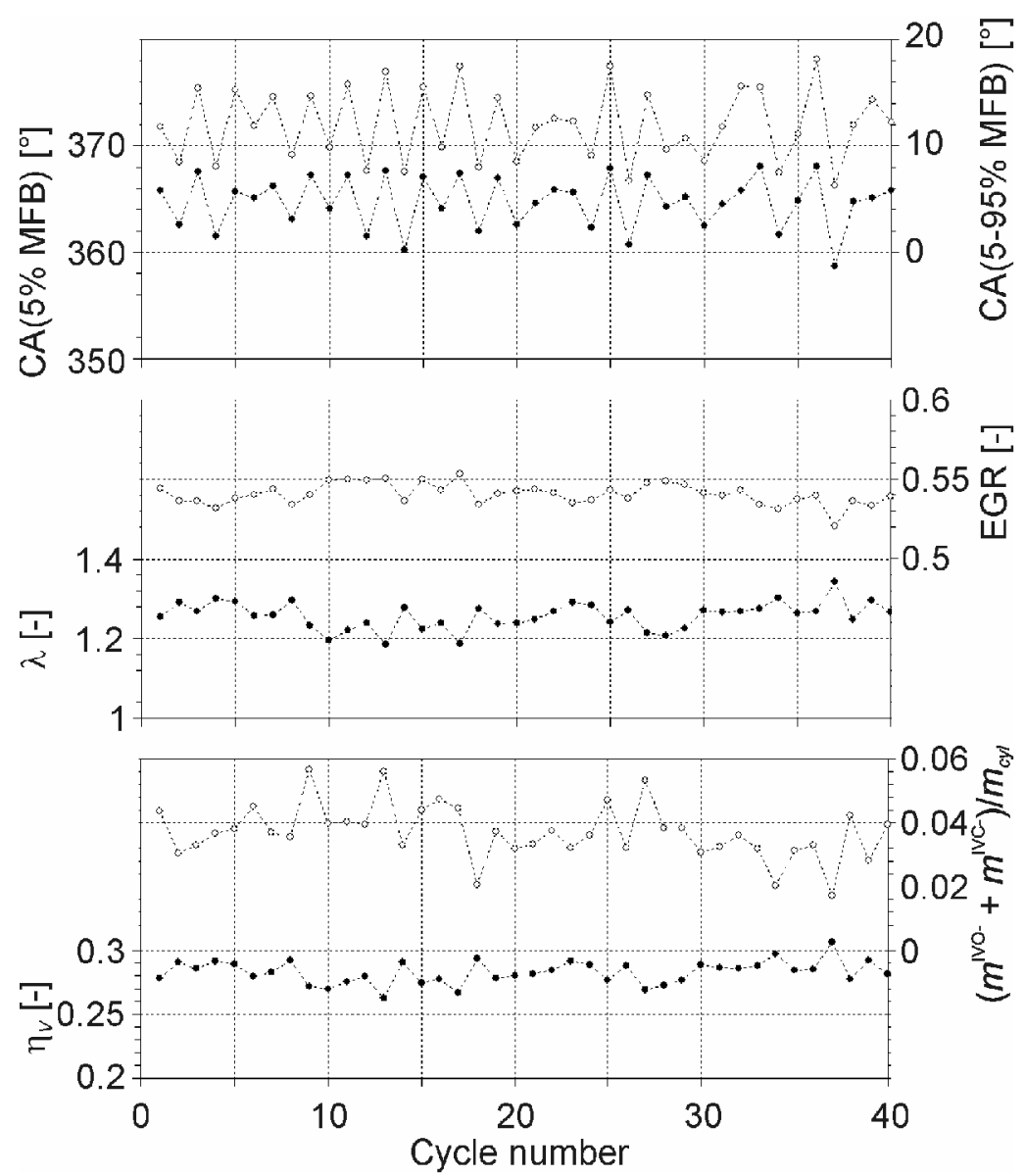

Fig. 10. Crank angle at 5\% MFB, combustion duration, air excess coefficient, EGR rate, volumetric efficiency and backflow rate for 40 consecutive engine cycles

Rys. 10. Kąt wypalenia 5\% dawki paliwa, kąt spalania, współczynnik nadmiaru powietrza, współczynnik recyrkulacji spalin, współczynnik napetnienia oraz współczynnik przepływów zwrotnych dla 40 kolejnych cykli pracy silnika

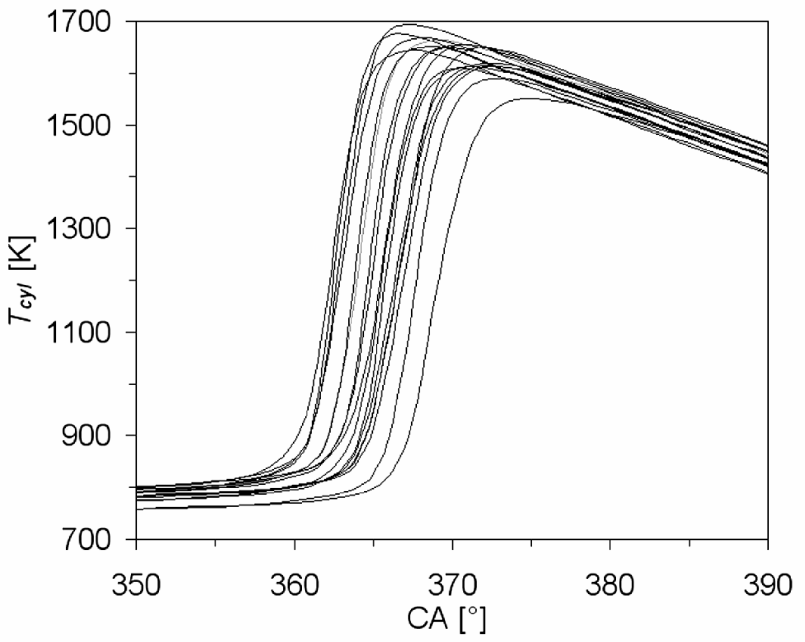

Fig. 9. The in-cylinder temperature variability

Rys. 9. Zmienność temperatury w cylindrze

mowano stosunek sumy mas czynnika przepływającego do kanału dolotowego w początkowej i w końcowej fazie procesu dolotu do całkowitej masy ładunku w cylindrze po zamknięciu zaworu dolotowego.

Ponieważ ilość powietrza jaka dostanie się do cylindra zdeterminowana jest przez ilość recyrkulowanych wewnętrznie spalin, to właśnie temperatura w trakcie procesu wylotu determinuje przebieg procesu spalania w kolejnym cyklu. Szybkie wywiązywanie się ciepła wiąże się z obniżeniem temperatury spalin, co w efekcie zwiększa współczynnik recyrkulacji spalin w kolejnym cyklu. Wynikający z tego spadek współczynnika napełnienia spowalnia proces spalania w kolejnym cyklu. Ponieważ paliwo wtryskiwane jest bezpośrednio do cylindra, jego masa nie ulega większym zmianom. Jednakże zmiany współczynnika nadmiaru powietrza nieco kompensują zmienność procesu spalania wynikającą z ilości powietrza w cylindrze.

\section{Wnioski}

Benzynowy silnik HCCI z wewnętrzną recyrkulacją spalin może pracować w szerokim zakresie obciążeń bez konieczności sterowania przebiegiem procesu wywiązywania się ciepła w zamkniętej pętli sprzężenia zwrotnego. Dostrzeżone zależności pomiędzy współczynnikiem napełnienia, współczynnikiem wewnętrznej recyrkulacji spalin oraz temperaturą spalin stanowią mechanizm samoregulacji, zapewniający właściwy przebieg krzywych sprężania, skutkujący samozapłonem w pobliżu górnego zwrotnego położenia tłoka.

Na podstawie analizy zmienności cyklicznej procesu roboczego stwierdzono, że zmienność ta, w przeciwieństwie do silników o zapłonie iskrowym [13], ma charakter deterministyczny. 
relationship between the volumetric efficiency, the internal EGR rate and the exhaust temperature.

The analysis of the cyclic variability of the in-cylinder processes showed that in contrast to spark ignition engines [13], HCCI engines disclose a deterministic character of the cycle-to-cycle phenomena. This mechanism is the same as the one identified at variable engine loads. Additionally, the backflows of the fluid from the cylinder to the intake port play an important role in the cyclic fluctuations.
Mechanizm, który odpowiada za zmienność cykliczną jest taki sam jak ten, który zapewnia możliwość pracy silnika przy zmiennych obciążeniach. Ponadto w cyklicznej zmienności procesu roboczego znaczną rolę odgrywają przepływy zwrotne czynnika z cylindra do kanału dolotowego.

Paper reviewed/Artykut recenzowany

\section{Nomenclature/Skróty i oznaczenia}

CA Crankshaft Angle/kat obrotu watu korbowego

cyl Cylinder/cylinder

EGR Exhaust Gas Recirculation/recyrkulacja spalin

EV Exhaust Valve/zawór wylotowy

EVC Exhaust Valve Closing/zamknięcie zaworu wylotowego

exh Exhaust/spaliny

HCCI Homogeneous Charge Compression Ignition/samozapłon mieszanek jednorodnych

IMEP Indicated Mean Effective Pressure/średnie ciśnienie indykowane

IV Intake Valve/zawór dolotowy

IVC Intake Valve Closing/zamknięcie zaworu dolotowego
IVO Intake Valve Opening/otwarcie zaworu dolotowego

$\eta_{\mathrm{v}} \quad$ Volumetric efficiency/wspótczynnik napetnienia

1 Lift of a valve/wznios zaworu

$\lambda \quad$ Air excess ratio/wspótczynnik nadmiaru powietrza

m Mass/masa

MFB Mass Fraction Burnt/stopień wypalenia dawki paliwa

NVO Negative Valve Overlap/ujemne współotwarcie zaworów

SOC Start of Combustion/poczatek spalania

$\mathrm{T}$ Temperature/temperatura

p Pressure/ciśnienie

V Volume/objętość

$\psi \quad$ Mixture dilution ratio/stopień rozrzedzenia ładunku

\section{Bibliography/Literatura}

[1] Heywood J.: Internal combustion engine fundamentals. McGraw-Hill Book Company, 1988.

[2] Hunicz J.: Combustion control in gasoline HCCI engine with direct fuel injection and exhaust gas trapping. Journal of KONES Powertrain and Transport. Vol. 17, No. 2, 2010.

[3] Hunicz J., Kordos P.: An experimental study of fuel injection strategies in CAI gasoline engine. Experimental Thermal and Fluid Science, Vol. 35, Issue 1, pp. 243-252, 2011.

[4] Hunicz J., Kordos P.: Experimental study of the gasoline engine operated in spark ignition and controlled auto-ignition combustion modes. SAE Technical Paper no 2009-01-2667, 2009

[5] Hunicz J., Niewczas A., Kordos P.: Research into a gasoline HCCI engine. Combustion Engines, Vol. 140, pp. 3-13, 2010.

[6] Kim J.N., Kim H.Y., Yoon S.S., Sa S.D., Kim W.T.: Effect of valve timing and lift on flow and mixing characteristics of a CAI engine, Int. Journal of Automotive Technology. vol. 8, no. 6, pp. 687-696, 2007.

[7] Koopmans L., Backlund O., Denbratt I.: Cycle to cycle variations: Their influence on cycle resolved gas temperature and

Jacek Hunicz, DEng. - doctor in the Faculty of Mechanical Engineering at Lublin University of Technology.

Dr inż. Jacek Hunicz - adiunkt na Wydziale Mechanicznym Politechniki Lubelskiej.

e-mail:jhunicz@pollub.pl

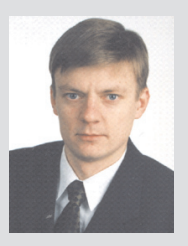

unburned hydrocarbons from a camless gasoline compression ignition engine. SAE Technical Paper 2002-01-0110, 2002.

[8] Lee C.H., Lee K.H.: An experimental study of the combustion characteristics in SCCI and CAI based on direct-injection gasoline engine. Experimental Thermal and Fluid Science, vol. 31, pp. 1121-1132, 2007.

[9] Mahrous A-F.M., Potrzebowski A., Wyszyński M.L., Xu H.M., Tsolakis A., Łuszcz P.: A modelling study into the effects of variable valve timing on the gas exchange process and performance of a 4-valve DI homogeneous charge compression ignition (HCCI) engine. Energy Conversion and Management, vol. 50, pp. 393-398, 2009.

[10] Shaver G.M., Roelle M.J., Gerdes J.Ch.: Modeling cycle-tocycle dynamics and mode transition in HCCI engines with variable valve actuation. Control Engineering Practice, vol. 14, pp. 213-22, 2006.

[11] Wildman C., Scaringe R.J., Cheng W.K.: On the maximum pressure rise rate in boosted HCCI operation. SAE Technical Paper 2009-01-2727, 2009.

[12] Yamaoka S., Kakuya H., Nakagawa S., Nogi T., Shimada A., Kihara Y.: A study of controlling the auto-ignition and combustion in a gasoline HCCI engine, SAE Technical Paper 2004-01-0942, 2004.

[13] Zervas E.: Correlations between cycle-to-cycle variations and combustion parameters of a spark ignition engine, Applied Thermal Engineering, vol. 24, pp. 2073-2081, 2004.

[14] Zhao H., Li J., Ma T., Ladommatos N.: Performance and analysis of a 4-stroke multi-cylinder gasoline engine with CAI combustion. SAE Technical Paper 2002-01-0420, 2002. 